\title{
Inter-settlement territories, their realities and prospects
}

\author{
Valeria Vylegzhanina ${ }^{1,}{ }^{*}$, Ilgiz Giniyatov ${ }^{2}$, Nadezhda Dobrotvorskaya ${ }^{2,3}$, Anastasia Ilinykh $^{2}$, \\ and Victor Timonov ${ }^{4}$ \\ ${ }^{1}$ Department of the Federal Service for State Registration, Cadastral Records and Cartography for \\ Novosibirsk Region, Novosibirsk, Russia \\ ${ }^{2}$ Siberian State University of Geosystems and Technologies, Novosibirsk, Russia \\ ${ }^{3}$ Siberian Federal Scientific Center of Agrobiotechnology RAS, Novosibirsk region, Russia \\ ${ }^{4}$ Kryachkov Novosibirsk State University of Architecture, Design and Arts (NSUADA), Novosibirsk, \\ Russia
}

\begin{abstract}
The paper presents the results of research and analysis of the state of agricultural land in the Novosibirsk region, located in intersettlement areas, considered the main reasons contributing to the degradation of agricultural land. The need for the formation of scientific approaches in solving the problems identified by the Government of the Russian Federation within the framework of the Doctrine of Food Security of the Russian Federation, which provides for the development of the agroindustrial complex, which allows providing the population of the country with high-quality, affordable and safe agricultural products, has been substantiated. It is proposed to form "exchange zones" in each region of the country, which should include the scientific community represented by representatives of specialized higher educational institutions with the involvement of production structures, Rosreestr (Russian State Register), regional ministries of agriculture, ensuring the implementation of the state agro-industrial policy. The concept of a system of step-by-step work is proposed, aimed at the rational use of agricultural land in the framework of managing the development of inter-settlement territories.
\end{abstract}

\section{Introduction}

The agro-industrial complex (AIC) of the Russian Federation requires close attention not only from the Government of the Russian Federation, legislative and executive authorities, and the economic entities themselves. It also requires a scientifically grounded approach to solving problems and problems that arise and are formed as a result of the ongoing socioeconomic processes and phenomena in the agricultural sector [1]. In recent years, there has been a tendency to enlargement of agricultural enterprises, the formation of latifundia, as well as the creation of agro-industrial holdings producing various agricultural products. Large peasant farm enterprises occupy a certain place in the competition [2]. At the same time, the regulatory authorities often face unscrupulous owners of agricultural land,

\footnotetext{
* Corresponding author: valeria741974@mail.ru
} 
ineffective management, and often their inaction leads to land degradation due to downtime and overgrowing of cultivated areas with bushes and weeds [3].

The purpose of this article is a general analysis of the state of agricultural land on the territory of the Novosibirsk region and, in particular, the study of the impact of the activities of agricultural enterprises on the development of inter-settlement territories. As a result of the research, proposals were prepared for the formation of scientific approaches within the framework of managing the development of inter-settlement territories.

\section{Materials and research methods}

The object of research is agricultural land located on the territory of the Novosibirsk region, including lands within the Novosibirsk agglomeration, located in the Kochenevsky district of the Novosibirsk region. As a result of the analysis of the state of agricultural lands and the presentation of the research results, the materials of remote sensing of the Earth were used; data of the public cadastral map posted on the Rosreestr website; official information published on the websites of Novosibirskstat (Federal State Statistics Service for the Novosibirsk region), the Ministry of Agriculture of the Novosibirsk Region, the Government of the Novosibirsk Region; information posted on the official website of the administration of the Kochenevsky district in the Novosibirsk region; official information posted on the Rosselkhoznadzor( Federal Service for Veterinary and Phytosanitary Surveillance) website for the Novosibirsk region.

\section{Results and discussion}

The Doctrine of Food Security of the Russian Federation (Doctrine) [4], which was approved by the President of the Russian Federation in 2020, is aimed at developing and implementing comprehensive measures to provide the country's population with highquality, affordable and safe agricultural products, which also implies the country's independence in this area. All this once again confirms the need for the rational use of agricultural land, laying this aspect in the tasks of rule-making and the principles of implementing state policy in this area.

The tasks of the Doctrine are, among other things, to provide conceptual scientific approaches that provide for the stage-by-stage development and implementation of complex measures using new modern technologies. At the same time, the optimal performance of work implies, in our opinion, the study and analysis of the state of agricultural land, the quantitative and qualitative characteristics of economic entities, the collection and study of information on the natural, landscape and climatic characteristics of the territories, ground and underground facilities of the existing infrastructure that ensures the economic activity of agro-industrial enterprises. In addition, it is necessary to pay attention to those territories where there was a decrease or termination of agricultural activity in order to assess the economic efficiency of the creation of new enterprises and associations or the revival of lost agricultural activities. These works will allow you to prepare and update all the necessary information for planning and designing the development of territories in general.

Considering the general picture in the agricultural sector, the following can be noted.

The difficult socio-economic situation that has developed in recent years has significantly contributed to the ruin of small peasant farm enterprises (PFEs), the creation of large agricultural holdings and the emergence of latifundia [2]. More or less stable and strong PFEs in the process of carrying out agricultural activities monitor the condition of the lands they cultivate. But the ruined PFEs, as well as the latifundia formed in their place, 
cause the degradation of lands in this category. As an example we can cite the official information posted on the website of the Rosselkhoznadzor Departments for the Tver and Yaroslavl Regions, according to which the latifundists, who bought up agricultural land located in these regions for a pittance, use no more than $5 \%$ of the total land area for their intended purpose. The rest of the cultivated areas are overgrown with shrubs and weeds [3]. On the territory of the Novosibirsk region there are also lands of this category, which are in an unsatisfactory condition. According to the Rosselkhoznadzor Directorate for the Novosibirsk Region, as a result of scheduled inspections of several separate municipal units in the region's districts in 2019, about 29,520 hectares of uncultivated agricultural land were identified, where the overgrowth process is in full swing, and about 152 hectares of land are occupied by unauthorized dumps of solid household waste [5]. According to the information on the results of work of the agro-industrial complex of the Novosibirsk region in 2020, the number of sown areas increased by 46.3 thousand hectares compared to 2019 . The increase in acreage is a consequence of the policy pursued in the framework of the Doctrine [4] by the Government of the Novosibirsk Region to support and develop PFEs, including small forms of farming [6]. At the same time, the decline in agricultural activities of personal subsidiary plots continues [6]. This circumstance, in our opinion, is due to the outflow of the local population to larger settlements for the purpose of employment and more comfortable living and, accordingly, the impoverishment of rural areas by the ablebodied population. A detailed analysis of some individual agricultural enterprises and личных PFEs in the territory of the Novosibirsk region shows the following picture. According to a press release from the Rosselkhoznadzor Directorate for the Novosibirsk Region, in September 2019, inspectors of the State Land Supervision Department of the Rosselkhoznadzor Directorate for the Novosibirsk Region carried out a scheduled field inspection in relation to the administration of the Kremlin Village Council of the Kochenevsky District. As a result of the control and supervisory measures, no violations of the land legislation of the Russian Federation were revealed [5]. However, let us turn to public data. According to the public cadastral map of Rosreestr, within the boundaries of the specified village council, there is a land plot with cadastral number 54: 11: 017016: 593, which belongs to agricultural land and has a permitted use - for agricultural production, the area of which is 16845.493 hectares [7]. Until 2017, the farmland was leased by the federal state unitary enterprise FSUE "Kremlevskoye" of the Russian Agricultural Academy, which specialized in seed production and cattle breeding. In 2019, it was liquidated as a result of bankruptcy proceedings $[8,9]$. These lands are state property, in 2017 they were leased to a legal entity - "Agrosib" Limited Liability Company, whose main activity is the cultivation of cereals (except for rice), legumes and oilseeds. General analysis of the data indicating the economic activity of the lessee confirmed the stability of the entity in this sector of the economy [8].

For many years of active farming, the considered agricultural lands were systematically plowed without taking into account their agroecological properties [10]. However, the farming system in the Federal State Unitary Enterprise "Kremlin" in the Kochenevsky District of the Novosibirsk Region has always been focused on the preservation and reproduction of soil fertility by sowing perennial grasses in large areas. The relatively high grain yield was ensured by the use, albeit limited, of fertilizers and plant protection products. At the same time, according to remote sensing data, part of the land has been removed from cultivation (Figures 1,2). 


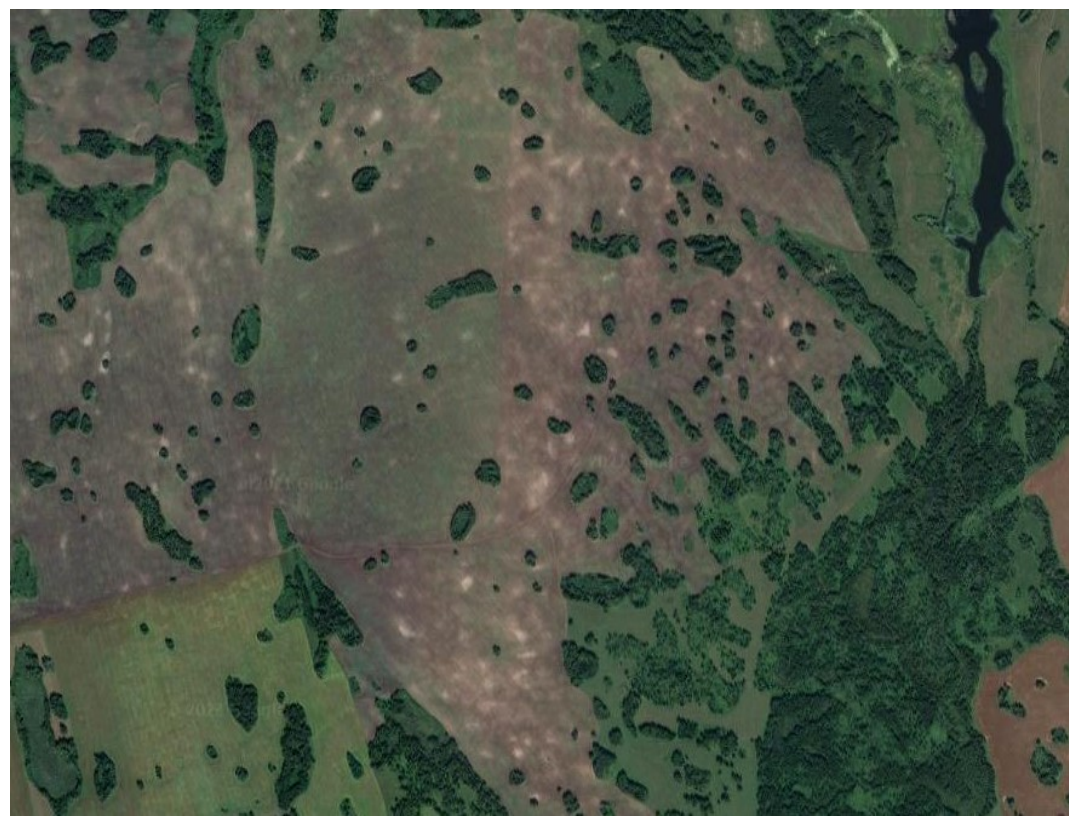

Fig. 1. Untreated arrays of fields on the territory of the Federal State Unitary Enterprise "Kremlin" of the Kochenevsky district of the Novosibirsk region (snapshot of 2021, Google maps program, scale 1:40 000).

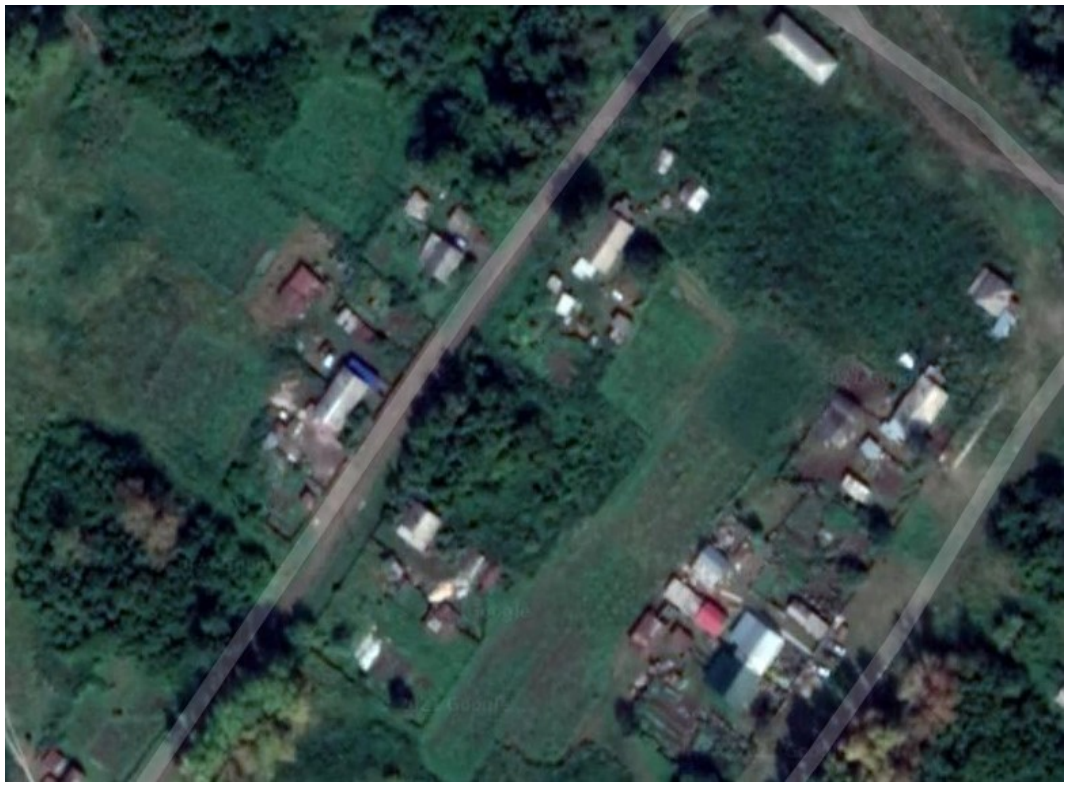

Fig. 2. Overgrowth of agricultural land on the territory Pervomaisky settlement of the Kremlin Village Council of the Kochenevsky District Novosibirsk region (snapshot of 2021, Google maps program, scale 1: 5000).

Thus, the problem of agricultural land overgrowth is urgent and there are discrepancies between official statistics and reality. In order to eliminate such inconsistencies, it is proposed to carry out an agricultural microcensus in all regions of the Russian Federation [11]. This work has already begun in August 2021. Its goal is to cover all agricultural 
organizations and all farms. In addition, a sample survey of personal subsidiary plots is supposed [11]. As the head of Rosstat said, "a census taker will not come to a private household if it is located in the city or in an urban-type settlement, in small villages (where there are less than 10 households), as well as in private households located in remote areas of the country" [12]. At the same time, a survey of hard-to-reach territories can be carried out using satellite monitoring data obtained as a result of overflights of unmanned aerial vehicles [11]. Thus, for the first time, a survey of agricultural land will be carried out using this technology. According to the results of the agricultural microcensus, there will be upto-date information on the number of operating agricultural entities. The collection and accumulation of the rest of the above information is possible within the framework of the "exchange zone" [13], which may include both specialized higher educational institutions and research institutes. At the same time, one cannot discount the need for regional divisions of Rosreestr to participate in this process, since this department is working to update information in the Unified State Register of Real Estate, including in relation to agricultural land and land users of this category. These measures also need to be coordinated with the regional Ministry of Agriculture, since this executive authority carries out state management and legal regulation in the field of the agro-industrial complex.

\section{Conclusions}

The results obtained in this work allow us to draw some conclusions. The negative impact of socio-economic processes and phenomena occurring in the agricultural sector of the Russian Federation caused a decrease in the number of employable population in rural areas and its outflow to large cities, the destruction of medium and small peasant farms, which, in turn, contributed to an active increase in the degradation of arable lands as a result of the lack of necessary agricultural measures on them. The formation of latifundia also negatively affects the state of agricultural land, since in this case the land becomes a means of capitalization, and not a means of production in the implementation of agricultural activities, which directly contradicts the basic principles of land legislation.

The activities of the Government of the Russian Federation are aimed at developing and implementing a policy for the development of the agro-industrial complex and sustainable development of territories. However, for obvious reasons, it cannot cover all the necessary areas of activity and, in particular, the regional and local level. For the successful implementation of these activities, in our opinion, it is necessary to carry out the following works:

- creation of "exchange zones", in terms of which complex measures will be carried out to study the territory of municipalities and inter-settlement territories, each separate district of the region in terms of the availability of agricultural land, the location of the existing and lost engineering infrastructure, and the collection of information on landscapeadaptive farming;

- within the framework of land management design, it is necessary to prepare design solutions for the development of inter-settlement territories from the point of view of the rational use of agricultural land and recommendations on the quantitative and qualitative optimization of agricultural enterprises and organizations of each type of agricultural activity;

- preparation of design solutions for on-farm land management of the above agricultural enterprises;

- preparation of design solutions for the development of agritourism and attraction of the employable population, including pensioners, in order to strengthen the labor force in the development of agricultural enterprises; 
— preparation of design solutions for the logistics of processing, storage and marketing of agricultural products produced by enterprises within the region and beyond;

- preparation of an economic feasibility study to optimize the quantitative and qualitative state of agricultural enterprises with an address reference to the territory of each district of the region;

- preparation of research projects for their participation in competitive selections for the right to receive grants and subsidies in the framework of government measures to support the agro-industrial complex.

Thus, the implementation of an integrated scientific approach to solving problems and problems that have emerged in the agro-industrial sector will not only meet the needs of society within the framework of the Food Security Doctrine [4], but also manage the development of inter-settlement territories in terms of conservation and rational use of agricultural land, referred to the category of lands specially protected by the state.

The above activities can be considered as a kind of concept of a system of step-by-step work aimed at the rational use of agricultural land within the framework of managing the development of inter-settlement territories.

\section{References}

1. O. I. Rusakova, Izvestia BSU, 1 (2006)

2. D. M. Khomyakov, Agriculture failed to remain the main driver of the Russian economy (2018)

3. Rosselkhoznadzor in Tver and Yaroslavl regions latifundists, http://rshn-tver.ru/

4. Decree of the President of the Russian Federation as of January 21, $2020 \mathrm{~N} 20$ "On Approval of the Food Security Doctrine of the Russian Federation", http://www.consultant.ru

5. Website of the Rosselkhoznadzor of the Novosibirsk region, http://rshn-nso.ru/

6. Official website of the Ministry of Agriculture of the Novosibirsk Region, http://mcx.nso.ru/

7. Official website of Rosreestr. Public cadastral map, https://pkk.rosreestr.ru/

8. Electronic service "SBIS", https://sbis.ru/

9. Electronic version of the newspaper "Kommersant", https://www.kommersant.ru/

10. N. Vlasenko, N. I. Dobrotvorskaya, L. N. Iodko, I. N. Sharkov and et al., A model of adaptive landscape agriculture and agricultural technologies (on the example of the Federal State Unitary Enterprise "Kremlin" of the Kochenevsky district of the Novosibirsk region), 200 (2012)

11. Official portal of the Government of the Rostov region, https://www.donland.ru/

12. Electronic version of the business newspaper, https://www.donland.ru/

13. E. I. Avrunev, V. V. Vylegzhanina, I. A. Giniyatov, V. A. Timonov, International scientific and methodological conference "Topical issues of education. A model of problem-oriented project-based education in a modern university " (2021) 